\title{
Removal of Heavy Metals from Tie and Dye (Adire) Wastewater Using Low-Cost Adsorbents
}

\author{
Adebola Adebayo Adekunle*, Ayokunle Oluwaseun Familusi, Bukunmi Ayomide Amoo, Adebayo Samuel Akinsanya, Fidelis Nkeshita
}

\begin{abstract}
Rapid industrialization has succeeded in constantly releasing hazardous heavy metals into the environment; however the need to minimize this risk has become a global concern. This study is to investigate the effectiveness of rice husk, sawdust and sugarcane bagasse as low cost adsorbents in heavy metals removal and to reduce the environmental pollution caused by these heavy metals. Columns of four different adsorbents (rice husk, sawdust, sugarcane bagasse and the mixture of the three) were set up and the Adire wastewater was passed through them. The adsorbents, the effluents and the filtrates were taken for physico-chemical and heavy metals analyses. The results showed that sugarcane bagasse adsorbent is the most effective in the physical and chemical treatment of the wastewater used, while the sawdust adsorbent is most effective in the removal of Copper, Chromium, Nickel and Iron.
\end{abstract}

Keywords: adsorbents; heavy metals; pollution; wastewater

\section{INTRODUCTION}

The removal of metal ions from effluents is important to many countries of the world both for environmental safety and for water re-use. Heavy metals have been excessively released into the environment due to rapid industrialization and have created a major global concern. Cadmium, Zinc, Copper, Nickel, Lead, Mercury and Chromium are often detected in industrial wastewaters, which originate from metal plating, mining activities, smelting, battery manufacture, tanneries, petroleum refining, paint manufacture, pesticides, pigment manufacture, printing, photographic industries, etc. (as cited in [1]). In addition, soil is a great geochemical reservoir for contaminant as well as a natural buffer for transportation of chemical materials and elements in the atmosphere, hydrosphere, and biomass. For this, it is the most important component of the human biosphere. As soil is an important constituent of the human biosphere, any harmful change to this segment of the environment seriously affects the overall quality of human life. The most adverse effect of heavy metals is that they can be introduced into the food chain and threaten human health [2].The search for low-cost adsorbents that have pollutantbinding capacities is extremely meaningful for efficient water and wastewater treatment. It was confirmed by [3] that the quality of drinking water, especially in developing countries can be enormously improved by the use of claysawdust composite filter. They submitted further that well water, harvested rainwater as well as surface runoff can be converted to potable water by subjecting them to filtration using Point-of-Use (POU) filters as this will go a long way to reduce the burden of water-borne diseases in developing countries and also ensure sustainable water supply. Sugarcane bagasse can be one of the materials to separate oil and water as an alternative method of separation. This alternative method can be used as one of the methods to separate oil from water for cleaning the waste oil from oil spills as well as a method to separate oil from palm oil industrial waste [4], similarly Sugar Cane Bagasse based Activated Carbons (SCBACs) were extremely viable adsorbents for application in the removal of phenol from aqueous solutions [5]. The properties of ceramic filter manufactured from local material clay and additives (sawdust and rice husk) by two simple techniques (slip casting and semi-dry pressing) were worked upon by [6] They concluded that the slip casting technique was a more suitable procedure for producing a porous ceramic filter. The freely abundant, locally available, low-cost adsorbent like Teff straw can be treated as economically viable for the removal of metal ions from textile effluents [7], and the fixed bed column treatment system as proposed by [8] is appropriate and suitable domestic approach to arsenic removal in local areas, because of its simplicity, easy operation and handling. By-products of agricultural materials such as rice husk, sawdust and sugarcane bagasse which require little processing and are abundant in nature have been effective for removal of heavy metals from wastewater. These low cost adsorbents are valuable alternatives for commercial sorbents. However, the contamination levels in soil or water bodies can be determined from the index of geoaccumulation $\left(I_{\mathrm{geo}}\right)$ shown in Tab. 1(as cited in [2] and [9]).

Table 1 Index of geoaccumulation (Igeo) for contamination levels in soil/water bodies

\begin{tabular}{|c|c|l|}
\hline$I_{\text {geo }}$ Class & $I_{\text {geo }}$ Value & \multicolumn{1}{|c|}{ Contamination Level } \\
\hline 0 & $I_{\text {geo }} \leq 0$ & Uncontaminated \\
\hline 1 & $0<I_{\text {geo }}<1$ & Uncontaminated/moderately contaminated \\
\hline 2 & $1<I_{\text {geo }}<2$ & Moderately contaminated \\
\hline 3 & $2<I_{\text {geo }}<3$ & Moderately/strongly contaminated \\
\hline 4 & $3<I_{\text {geo }}<4$ & Strongly contaminated \\
\hline 5 & $4<I_{\text {geo }}<5$ & Strongly/extremely contaminated \\
\hline 6 & $5<I_{\text {geo }}$ & Extremely contaminated \\
\hline
\end{tabular}

The aim of this project is to investigate the effectiveness of rice husk, sawdust and sugarcane bagasse as low-cost adsorbents in heavy metals removal and to reduce the environmental pollution caused by the heavy metals.

\section{EXPERIMENTAL}

\subsection{Materials and Equipment Required for the Study}

The materials and equipment used include:

- Adire wastewater collected from Itoku market, Abeokuta

- Rice husk obtained at Imota, Lagos State

- Sawdust 
- Sugarcane bagasse

- Distilled water

- Sieve

- Infusion sets

- Filtering media

- Separating columns (plastic bottles).

\subsection{Experimental Procedure}

2.2.1 Preparation of Rice Husk

The rice husk obtained from Idumota, Lagos State, was washed with distilled water to remove surface impurities and dried under the sun for 24 hours. The dried rice husk was further ground to increase the surface area and later sieved using $1 \mathrm{~mm}$ sieve size.

\subsubsection{Preparation of Sawdust}

The sawdust obtained from Camp Sawmill, Abeokuta was washed with distilled water to remove surface impurities and dried under the sun for 24 hours. The dried material was sieved using sieve size $1 \mathrm{~mm}$.

\subsubsection{Preparation of Sugarcane Bagasse}

The back peel of sugarcane was collected from local Hausa sellers and sun-dried for 24 hours. The dried samples were heated or burnt leaving the ash residue. The ash was further ground using pestle to increase the surface area of the material. Sugarcane bagasse obtained was passed through 1 $\mathrm{mm}$ sieve before use.

\subsubsection{Wastewater Sample Collection}

The wastewater was collected using grab sampling method. The process involved a single sample taken at a specific time or over as short a period as feasible. Sample bottle was rinsed first with ordinary water and then distilled water, before pouring the sample in the sample bottle. The coordinates of the location being N7.1568450 and E3.3423530.

\subsubsection{Filters Set-Up and Filtration}

The setup of the filters was done using a $75 \mathrm{cl}$ plastic bottle for the column experiment and a retort stand was used to hold the bottle firm for the experiment. The adsorbents were poured in the plastic bottle $(75 \mathrm{cl})$ at a height of $15 \mathrm{~cm}$ mark. The cover of the bottle was bored and a filtering media (light cloth) was used to prevent blockage and ease the discharge of the effluents. The infusion set was fixed to one end of the bottle and the other part to the effluent bottle. The weight of the rice husk, sawdust, sugarcane bagasse and the mixture of the three was found to be $2.06 \mathrm{~g}, 1.08 \mathrm{~g}, 1.54 \mathrm{~g}$ and $1.60 \mathrm{~g}$ respectively. The mixture was arranged as sugar cane bagasse, sawdust and rice husk in ascending order of the set up. After the setup of the filters, the Adire wastewater was then passed through each of the four filters

\subsubsection{Batch Sorption Experiment}

Batch adsorption experiment was performed at different temperatures and initial concentrations to obtain equilibrium isotherms. In order to obtain the adsorption capacity, the number of ions adsorbed per mass unit of the agricultural byproduct was evaluated using the following expression:

$Q_{\mathrm{e}}=\frac{\left(C_{0}+C_{\mathrm{e}}\right) \cdot V}{m}$

Where $Q_{\mathrm{e}}$ is the amount adsorbed at equilibrium $(\mathrm{mg} / \mathrm{g}), C_{0}$ is the initial metal ions concentration $(\mathrm{mg} / \mathrm{l}), C_{\mathrm{e}}$ is the equilibrium metal ions concentration $(\mathrm{mg} / \mathrm{l}), V$ is the volume of the aqueous phase (1), and $m$ is the amount of the adsorbent used (g).

\subsubsection{Physico-Chemical and Heavy Metals Analyses}

The effluents and the adsorbents were taken to LAGOS STATE ENVIRONMENTAL PROTECTION AGENCY to carry out the parameter tests. Initial and final concentrations of metals were determined by atomic absorption spectroscopy (AAS).

\section{RESULTS AND DISCUSSION}

The results of the physio-chemical and heavy metal analyses of the effluents, the filtrates and the adsorbents are as shown in Tabs. 2-5.

Table 2 Physical Analysis of the Effluents

\begin{tabular}{|c|c|c|c|c|c|}
\hline Physical Parameter & A & $\mathrm{B}$ & $\mathrm{C}$ & $\mathrm{D}$ & LASEPA Standard \\
\hline Colour & 4200 & 4137 & 2455 & 4110 & 250 Pt. Co. APHA \\
\hline Appearance & Deep brown with odour & Brownish with odour & Light brown with sediment & Brownish with odour & Clear \\
\hline Temperature ${ }^{\circ} \mathrm{C}$ & 24.8 & 24.8 & 25.0 & 24.9 & $\leq 40^{\circ} \mathrm{C}$ \\
\hline $\mathrm{pH}$ & 8.74 & 9.74 & 9.78 & 9.98 & $5.5-9.0$ \\
\hline Turbidity & 917 & 412 & 53.7 & 155 & NTU \\
\hline Conductivity & 44.89 & 28.02 & 10.07 & 11.3 & $\mathrm{mS} / \mathrm{cm}$ \\
\hline Total Suspended Solids & 830 & 1076 & 413 & 495 & $25 \mathrm{mg} / 1$ \\
\hline
\end{tabular}

The effluent from sample D (combination of the three adsorbents) has the highest $\mathrm{pH}$ (9.98) which relates with basicity from Tab. 2 above. Effluent from sample $\mathrm{C}$ (sugarcane bagasse) has the lowest Turbidity, Conductivity and Total Suspended Solids with values 53.7 NTU, 10.07 $\mathrm{mS} / \mathrm{cm}$ and $413 \mathrm{mg} / \mathrm{l}$ respectively in Tab. 2 above. This 
shows that sugarcane bagasse is the most effective in the physical treatment of the wastewater used. Chemical Oxygen Demand and Biochemical Oxygen Demand has its lowest value in sample $C$ of $758 \mathrm{mg} / \mathrm{l}$ and $189.5 \mathrm{mg} / \mathrm{l}$ respectively as shown in Tab. 3. Sample A has the highest COD and BOD of $7558 \mathrm{mg} / \mathrm{l}$ and $1889.5 \mathrm{mg} / \mathrm{l}$ respectively. This implies that sugarcane bagasse was the most effective in treating the chemical parameters of the wastewater.

Table 3 Chemical Analysis of the Effluents

\begin{tabular}{|l|c|c|c|c|c|}
\hline \multicolumn{1}{|c|}{ Chemical Parameter } & A & B & C & D & LASEPA Standard \\
\hline Chloride & 3870 & 2930 & 590 & 510 & $100 \mathrm{mg} / 1$ \\
\hline Nitrate & 0 & 3.0 & 1.3 & 0.15 & \\
\hline Phosphate & 0.35 & 0.17 & 5.56 & 0.71 & \\
\hline Sulphate & 0 & 0 & 0 & 1 & $100 \mathrm{mg} / 1$ \\
\hline Chemical Oxygen Demand & 7558 & 4605 & 758 & 2208 & $80.00 \mathrm{mg} / 1$ \\
\hline Biological Oxygen Demand & 1889.5 & 1151.25 & 189.5 & 552 & $20.00 \mathrm{mg} / 1$ \\
\hline
\end{tabular}

Table 4 Heavy Metals Analysis of the Effluents

Table 4 Heavy Metals Analysis of the Effluents
\begin{tabular}{|l|c|c|c|c|c|c|}
\hline $\begin{array}{c}\text { Trace/Toxic } \\
\text { Heavy Metals }\end{array}$ & A & B & C & D & E & $\begin{array}{c}\text { LASEPA } \\
\text { Standard }\end{array}$ \\
\hline Lead & 0.0012 & 0.0028 & 0.0004 & 0.0730 & 0.2182 & $0.1 \mathrm{mg} / 1$ \\
\hline Copper & 0.0011 & 0.0018 & 0.0026 & 0.0012 & 0.1102 & $0.5 \mathrm{mg} / 1$ \\
\hline Chromium & 0.0043 & 0.0207 & 0.0036 & 0.0127 & 0.6887 & $0.5 \mathrm{mg} / 1$ \\
\hline Nickel & 0.0011 & 0.0056 & 0 & 0.0041 & 0.3115 & $0.5 \mathrm{mg} / 1$ \\
\hline Zinc & 0.0106 & 0.0153 & 0.00037 & 0.00152 & 0.3894 & $2.0 \mathrm{mg} / 1$ \\
\hline Iron & 0.0388 & 0.0943 & 0.0693 & 0.02312 & 2.7447 & $\mathrm{NS}$ \\
\hline
\end{tabular}

Table 5 Heavy Metals Analysis of the Adsorbents

Table 5 Heavy Metals Analysis of the Adsorbents
\begin{tabular}{|l|c|c|c|c|c|c|}
\hline $\begin{array}{c}\text { Trace/Toxic } \\
\text { Heavy Metals }\end{array}$ & $\mathrm{A}$ & $\mathrm{B}$ & $\mathrm{C}$ & $\mathrm{D}$ & $\mathrm{E}$ & $\begin{array}{c}\text { LASEPA } \\
\text { Standard }\end{array}$ \\
\hline Lead & 0.2100 & 0.2130 & 0.2150 & 0.1420 & 0.2182 & $0.1 \mathrm{mg} / \mathrm{l}$ \\
\hline Copper & 0.1080 & 0.1070 & 0.1065 & 0.1080 & 0.1102 & $0.5 \mathrm{mg} / 1$ \\
\hline Chromium & 0.6840 & 0.6675 & 0.6840 & 0.670 & 0.6887 & $0.5 \mathrm{mg} / 1$ \\
\hline Nickel & 0.3100 & 0.3045 & 0.3110 & 0.3065 & 0.3115 & $0.5 \mathrm{mg} / \mathrm{l}$ \\
\hline Zinc & 0.3780 & 0.3735 & 0.3880 & 0.3878 & 0.3894 & $2.0 \mathrm{mg} / 1$ \\
\hline Iron & 2.7049 & 2.6500 & 2.6740 & 2.7205 & 2.7447 & $\mathrm{NS}$ \\
\hline
\end{tabular}

Key: A - Rice Husk; B - Sawdust; C - Sugarcane Bagasse; D - Rice Husk, Sawdust and Sugarcane Bagasse; E - Control Sample; NS - Not Specified; Pt. Co. APHA - Platinum Cobalt APHA Method

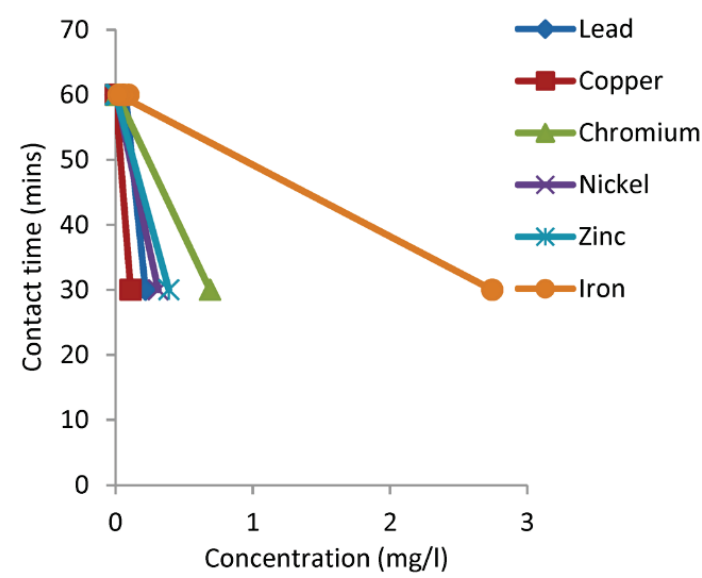

Figure 1 Adsorption Rate of Heavy Metals on the Effluents

The results of batch sorption experiment on the effluents, the filtrates and the adsorbents are as shown in Figs. 1-6. The volume $V=0.5 \mathrm{cl}$ and mass $m=2.06 \mathrm{~g}, 1.08 \mathrm{~g}, 1.54 \mathrm{~g}$ and $1.60 \mathrm{~g}$ for rice husk, sawdust, sugarcane bagasse and the three mixtures respectively. From Figs. 3-6, it can be deduced that sample D has the highest adsorption rate for Lead $(0.1775$ $\mathrm{mg} / \mathrm{g}$ ), Sample B has the highest adsorption rate for Copper $(0.0495 \mathrm{mg} / \mathrm{g})$, Chromium $(0.3090 \mathrm{mg} / \mathrm{g})$, Nickel $(0.1410$ $\mathrm{mg} / \mathrm{g}$ ) and Iron $(1.2269 \mathrm{mg} / \mathrm{g})$. This implies that Sample B, sawdust, is most effective in the removal of Copper,
Chromium, Nickel and Iron. Sample $\mathrm{C}$ has the highest adsorption rate for Zinc $0.126 \mathrm{mg} / \mathrm{g}$.

1) Rice Husk

For Lead $Q_{\mathrm{e}}=0.0510 \mathrm{mg} / \mathrm{g}$, for Copper $Q_{\mathrm{e}}=0.0262$ $\mathrm{mg} / \mathrm{g}$, for Chromium $Q_{\mathrm{e}}=0.1660 \mathrm{mg} / \mathrm{g}$, for Nickel $Q_{\mathrm{e}}=$ $0.0752 \mathrm{mg} / \mathrm{g}$, for Zinc $Q_{\mathrm{e}}=0.0917 \mathrm{mg} / \mathrm{g}$, for Iron $Q_{\mathrm{e}}=0.6565$ $\mathrm{mg} / \mathrm{g}$

2) Sawdust

For Lead $Q_{\mathrm{e}}=0.0986 \mathrm{mg} / \mathrm{g}$, for Copper $Q_{\mathrm{e}}=0.0495$ $\mathrm{mg} / \mathrm{g}$, for Chromium $Q_{\mathrm{e}}=0.3090 \mathrm{mg} / \mathrm{g}$, for Nickel $Q_{\mathrm{e}}=$ $0.1410 \mathrm{mg} / \mathrm{g}$, for Zinc $Q_{\mathrm{e}}=0.0017 \mathrm{mg} / \mathrm{g}$, for Iron $Q_{\mathrm{e}}=1.2269$ $\mathrm{mg} / \mathrm{g}$

3) Sugarcane Bagasse

For Lead $Q_{\mathrm{e}}=0.0698 \mathrm{mg} / \mathrm{g}$, for Copper $Q_{\mathrm{e}}=0.0346$ $\mathrm{mg} / \mathrm{g}$, for Chromium $Q_{\mathrm{e}}=0.2221 \mathrm{mg} / \mathrm{g}$, for Nickel $Q_{\mathrm{e}}=$ $0.1010 \mathrm{mg} / \mathrm{g}$, for Zinc $Q_{\mathrm{e}}=0.1260 \mathrm{mg} / \mathrm{g}$, for Iron $Q_{\mathrm{e}}=0.8682$ $\mathrm{mg} / \mathrm{g}$

4) Rice Husk, Sawdust and Sugarcane Bagasse

For Lead $Q_{\mathrm{e}}=0.1775 \mathrm{mg} / \mathrm{g}$, for Copper $Q_{\mathrm{e}}=0.0338$ $\mathrm{mg} / \mathrm{g}$, for Chromium $Q_{\mathrm{e}}=0.2097 \mathrm{mg} / \mathrm{g}$, for Nickel $Q_{\mathrm{e}}=$ $0.0973 \mathrm{mg} / \mathrm{g}$, for Zinc $Q_{\mathrm{e}}=0.1212 \mathrm{mg} / \mathrm{g}$, for Iron $Q_{\mathrm{e}}=0.8502$ $\mathrm{mg} / \mathrm{g}$.

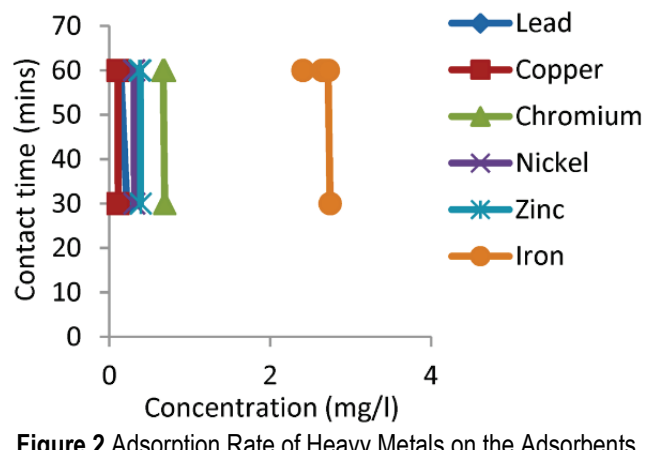

Tabs. 6 and 7 show that the sediments have a low contamination level based on Pollution Load Index (PLI) and uncontaminated $I_{\text {geo }}$ accumulation classification respectively.

$$
\begin{aligned}
& P L I=\left(C F_{1} \times C F_{2} \times C F_{3} \times \cdots \times C F_{n}\right)^{\frac{1}{n}} \\
& C F=\frac{\text { Metal concentration in the sediments }}{\text { Background value of the metal }}
\end{aligned}
$$


where $n$ is the number of metals and $C F$ is the Contamination Factor.



Figure 3 Adsorption of Heavy Metals by Rice Husk with $\mathrm{pH}$ of 8.74

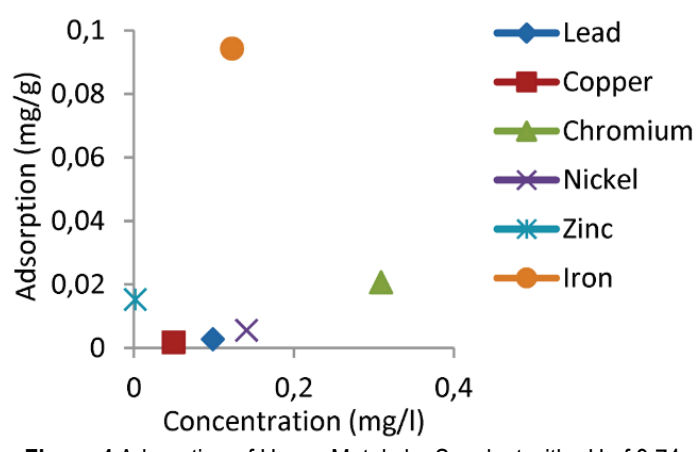

Figure 4 Adsorption of Heavy Metals by Sawdust with $\mathrm{pH}$ of 9.74

The $P L I$ of each metal was classified as either low ( $P L I$ $\leq 1)$, moderate $(1<P L I \leq 3)$ or high contamination $(P L I>3)$. Geo-accumulation Index $\left(I_{\text {geo }}\right)$ :

$$
I_{\text {geo }}=\log _{2}\left(\frac{C_{n}}{1.5 \times B_{n}}\right)
$$

Wher $C_{n}$ is the measured concentration of the metal $n$, within the sediment or size fraction; $B_{n}$ represents the background concentration of the metal $n$.

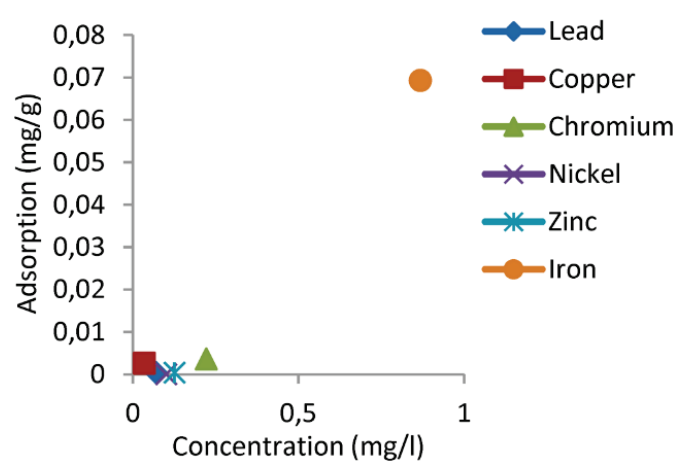

Figure 5 Adsorption of Heavy Metals by Sugarcane Bagasse with $\mathrm{pH}$ of 9.78

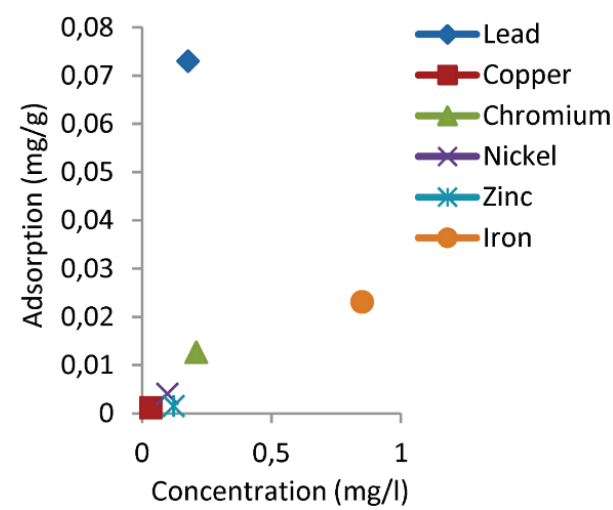

Figure 6 Adsorption of Heavy Metals by Rice Husk, Sawdust and Sugarcane Bagasse with $\mathrm{pH}$ of 9.98

Table 6 Contamination Factor and Pollution Load Indices of Heavy Metals

\begin{tabular}{|c|c|c|c|c|c|c|}
\hline Heavy Metals & $C F$ of $\mathrm{A}$ & $C F$ of $\mathrm{B}$ & $C F$ of $C$ & $C F$ of $\mathrm{D}$ & $P L I$ & Classification \\
\hline Lead & 0.96242 & 0.976169 & 0.985335 & 0.650779 & 0.9190 & low $(P L I \leq 1)$ \\
\hline Copper & 0.980036 & 0.970962 & 0.966425 & 0.980036 & 0.9828 & low $(P L I \leq 1)$ \\
\hline Chromium & 0.993176 & 0.969217 & 0.993176 & 0.972847 & 0.9880 & low $(P L I \leq 1)$ \\
\hline Nickel & 0.995185 & 0.977528 & 0.998395 & 0.983949 & 0.9925 & low $(P L I \leq 1)$ \\
\hline Zinc & 0.970724 & 0.959168 & 0.996405 & 0.995891 & 0.9869 & low $(P L I \leq 1)$ \\
\hline Iron & 0.985499 & 0.965497 & 0.974241 & 0.991183 & 0.9860 & low $(P L I \leq 1)$ \\
\hline
\end{tabular}

Table 7 Geo-accumulation Index of the Heavy Metals Sediment

\begin{tabular}{|l|c|c|c|c|c|}
\hline \multicolumn{1}{|c|}{ Heavy Metals } & $I_{\text {geo }}$ of A & $I_{\text {geo }}$ of B & $I_{\text {geo }}$ of C & $I_{\text {geo }}$ of D & Classification \\
\hline Lead & -0.6402 & -0.6198 & -0.6063 & -1.2047 & Uncontaminated $\left(I_{\text {geo }} \leq 0\right)$ \\
\hline Copper & -0.6141 & -0.6275 & -0.6342 & -0.6141 & Uncontaminated $\left(I_{\text {geo }} \leq 0\right)$ \\
\hline Chromium & -0.5948 & -0.6275 & -0.5948 & -0.6247 & Uncontaminated $\left(I_{\text {geo }} \leq 0\right)$ \\
\hline Nickel & -0.5919 & -0.6178 & -0.5873 & -0.6083 & Uncontaminated $\left(I_{\text {geo }} \leq 0\right)$ \\
\hline Zinc & -0.6278 & -0.6451 & -0.5902 & -0.5909 & Uncontaminated $\left(I_{\text {geo }} \leq 0\right)$ \\
\hline Iron & -0.6060 & -0.6356 & -0.6226 & -0.5977 & Uncontaminated $\left(I_{\text {geo }} \leq 0\right)$ \\
\hline
\end{tabular}

Effect of Contact Time. The contact time of the adsorbents varied. The wastewater had a contact time of 1 hour with rice husk, sawdust and sugarcane bagasse, while it had a contact time of 30 minutes with the three adsorbents when mixed together. The average discharge was 0.0056 litres per minute $(1 / \mathrm{min})$. This implies that it will take 1.50 hours (One and a half hours) to get 0.51 (0.5 litres) of wastewater effluent. The effect on contact time on the adsorbents is direct. This means that as the contact time increases, the rate of adsorption of the heavy metals increases also. 


\section{CONCLUSION}

Agricultural by-products appear as effective and cheap sorbents for removal of heavy metals from wastewater. The sorption capacity of sawdust adsorbent was the most effective while the sugarcane adsorbent was the most effective in treating the physical and chemical pollutants of the wastewater.

\section{REFERENCES}

[1] Parmar, M. \& Thakur, L. S. (2013). Heavy Metal Cu, Ni and Zn: Toxicity, Health Hazards and their Removal Techniques by Low Cost Adsorbents: A Short Overview. International Journal of Plant, Animal and Environmental Sciences, 3(3), 143-157.

[2] Rahman, S. H., Khanam, D., Adyel, T. M., Islam, M. S., Ahsan, M. A., \& Akbor, M. A. (2012). Assessment of Heavy Metal Contamination of Agricultural Soil around Dhaka Export Processing Zone (DEPZ), Bangladesh: Implication of Seasonal Variation and Indices. Journal of Appl. Sci., 2, 584601. https://doi.org/10.3390/app2030584

[3] Nnaji, C. C., Afangideh, B. C., \& Ezeh, C. (2016). Performance Evaluation of Clay-Sawdust Composite Filter for Point of Use Water Treatment. Nigerian Journal of Technology (NIJOTECH), 35(4), 949-956. https://doi.org/10.4314/njt.v35i4.33

[4] Noor Atikah Binti Mohd Badruddin. (2012). Separation of Oil and Water Using Sugarcane Bagasse, Universiti Malaysia Pahang, Faculty of Chemical \& Natural Resources Engineering, Pahang. http://umpir.ump.edu.my/id/eprint/ 5120/1/CD6476.pdf

[5] Akl, M. A. A., Dawy, M. B., \& Serage, A. A. (2014). Efficient Removal of Phenol from Water Samples Using Sugarcane Bagasse Based Activated Carbon. Journal of Analytical\& Bio-analytical Techniques, 5(2), 1-12. https://doi.org/10.4172/2155-9872.1000189

[6] Shukur, M. M., Aswad, M. A., \& Bader, S. M. (2018). Effects of Sawdust and Rice Husk Additives on Physical Properties of Ceramic Filter. Journal of University of Babylon, Engineering Sciences, 26(1), 221-228.

[7] Desta, M. B. (2013). Batch Sorption Experiments: Langmuir and Freundlich Isotherm Studies for the Adsorption of Textile Metal Ions onto Teff Straw (Eragrostis tef) Agricultural Waste. Journal of Thermodynamics, 1-6. https://doi.org/10.1155/2013/375830

[8] Asif, Z. \& Chen, Z. (2017). Removal of Arsenic from Drinking Water Using Rice Husk. Journal of Applied Water Science, 7, 1449-1458. https://doi.org/10.1007/s13201-015-0323-x

[9] Rabee, A. M., Al-Fatlawy, Y. F., Abd-Al-Husain Najim Abd Own, \& Nameer, M. (2011). Using Pollution Load Index (PLI) and Geoaccumulation Index (I-Geo) for the Assessment of Heavy Metals Pollution in Tigris River Sediment in Baghdad Region. Journal of Al-Nahrain University, 14(4), 108-114. https://doi.org/10.22401/JNUS.14.4.14
Authors' contacts:

Adebola Adebayo Adekunle, Associate Professor

(Corresponding author)

Department of Civil Engineering,

College of Engineering,

Federal University of Agriculture,

P.M.B. 2240, Alabata Road, Abeokuta, Ogun State, Nigeria

E-mail: adebolamay@gmail.com

E-mail: adekunleaa@funaab.edu.ng

Ayokunle Oluwaseun Familusi, Lecturer M. Sc Department of Civil Engineering,

College of Engineering,

Federal University of Agriculture,

P.M.B. 2240, Alabata Road, Abeokuta, Ogun State, Nigeria

E-mail: ayomacfamilson@gmail.com

Bukunmi Ayomide Amoo, Graduate B. Eng

Department of Civil Engineering,

College of Engineering,

Federal University of Agriculture,

P.M.B. 2240, Alabata Road, Abeokuta, Ogun State, Nigeria

E-mail: amoobukunmi@gmail.com

\section{Adetayo Samuel Akinsaanya, Student}

Department of Civil Engineering,

College of Engineering,

Federal University of Agriculture,

P.M.B. 2240, Alabata Road, Abeokuta, Ogun State, Nigeria

E-mail: akinsanyaadetayo@gmail.com

Fidelis Nkeshita, Lecturer MSC Department of Civil Engineering, College of Engineering,

Federal University of Agriculture,

P.M.B. 2240, Alabata Road, Abeokuta, Ogun State, Nigeria

E-mail: nkeshitafc@funaab.edu.ng 